\title{
Research Trends in Integrating Tablet Computers with Learning in Primary Education
}

\author{
Puri Selfi Cholifah \\ Department of Elementary School Teacher Education \\ Universitas Negeri Malang \\ Malang, Indonesia \\ puri.selfi.fip@um.ac.id
}

\begin{abstract}
This study aimed to explore several studies to map their trends in the integration of mobile and tablet computer with learning in primary education. As many as eleven studies that had been undertaken from 2013 to 2017 were identified to conduct this simple meta-synthesis research. The research findings show that (1) the most common methodology used in the selected research is qualitative-descriptive learning method characterized by exploratory and case study designs; (2) the purposes of those studies are mostly to explore the process of an implementation, to describe the perceptions of its usage, and to analyze its positive and negative effects; (3) the mode used in the research is 1:1 system (one tablet for one student). Further explanations about the results and limitations of the research will be discussed below.
\end{abstract}

Keywords-Tablet computer, Mobile compute, Primary education, review

\section{INTRODUCTION}

Technology has a dynamic character that always changes from time to time. Something that is popular today might lose its reputation in a year period. The rapid development of technology affects all systems of the users' lives. For example, one common notion proposed by Prensky of digital natives or digital immigrants [1]. Prensky defined digital native that as a definitive term to describe students that are the "native speakers" of the digital language of the internet, video games, and computers [1]. A few decades after the world accepted the notion, the rapid change of technology posed some new terms to refer to young people today such as "YouTube Generation," "Net Generation," and "Generation M" (Generation Media) [2].

The use of technology has a crucial role in the education system since the digital era expands people's access to education, especially regarding the 21 st-century skills. The net generation students will have unpredictable ways to amplify their thinking, learning, communication, collaboration, and creation skills [3]. Such undeniable fact leads to the opinion about a more significant opportunity for the student to learn without any boundaries or "wall," which means that every student can access information through his own devices anywhere and anytime. It is all about the flexibility that allows students to study at their own pace [4].
One of the components that relatively close with the focus of this review is mobile technology. Mobile technology provides a spectrum of tools for teachers as well as new options for student-technology partnerships in learning [5]. This mobile technology-integrated learning method is supported by a wide range of interactive multimedia materials such as video, audio, and graphics that can be very useful to the student in learning with their preferences. Those facts lead to the comprehension of mobile devices as a technology that offers some compelling technical features. MacDonald and Creanor stated that many students use their phones to keep in touch with fellow students using SMS texting and to use its flexibility to learn in different places [4]. Furthermore, using a mobile device gives many more learning experiences such as using the text message feature, using smartphones which combine phones with handheld computers, using laptops or netbooks, and using MP3 players to access podcasts.

Nowadays, a massive wave of acceptance to children who use technology is commonly seen in the society. Many parents have introduced technology to their children from the stage of early childhood, especially handheld computing devices such as tablet computer and smartphone. The phenomenon continues until the stage of primary education, which relates to the golden era of children's development. The education systems of some countries have adopted technology into their core curricula, especially the use of the tablet in the learning process. Walling pointed some critical issues on how tablets are changing classrooms around the world namely (1) accessibility, (2) connected learning, (3) special needs, (4) assessment, and (5) textbooks [2].

Crucial to the academic success, the integration of tablet and mobile computer with the learning process has cultivated some studies that declare its positive and practical outcomes for students of primary schools [6]-[8]. However, using a tablet or mobile computer is also being controversial because it still carries some negative aspects besides its positive aspects. The enthusiasts of such supportive learning media still argue whether or not its implementation in low grades such as in primary or elementary schools is related to the school institutional function [9]. To further investigate the above argument, this paper explores several studies to map their 
trends in the integration of mobile computer and tablet with learning in primary education.

\section{METHOD}

This study used a meta-synthesis research method to map the research trends of the selected papers consisted of 11 studies gathered from the online database from 2013-2017. The databases were Science Direct, ERIC, and Wiley. The articles were accessed from TechTrends, Education Information Technology, Canadian Journal of Learning and Technology, Mathematics Education Research Journal, Journal of Education and Training Studies, Journal of Education and Practice, Journal of Educational Computing Research, Educational Research, Educational Psychology Review, Oxford Review of Education, and Early Child Development and Care. Furthermore, to specify the selection of the journals, keywords were used to search the papers. The keywords included tablet, mobile device, a mobile computer, primary education and elementary education. Table 1 presents the list of the selected papers.

TABLE I. SUMMARY OF SELECTED PAPERS

\begin{tabular}{|c|c|c|c|c|}
\hline Author & Methods & Participants & Country & Description of the study \\
\hline $\begin{array}{l}\text { Johnson, G. M } \\
{[10] .}\end{array}$ & Survey & $\begin{array}{l}12 \text { teachers from The } \\
\text { Educational Support Centre }\end{array}$ & Australia & $\begin{array}{l}\text { Described the perceptions of special education } \\
\text { teachers and teacher assistants in using iPads to face } \\
\text { the learning challenges faced by students with } \\
\text { special needs }\end{array}$ \\
\hline $\begin{array}{l}\text { van Deursen, A. J. A. M., } \\
\text { Ben Allouch, S., and Rujiter, } \\
\text { L. P. } \\
{[11]}\end{array}$ & $\begin{array}{l}\text { Experiment and } \\
\text { Qualitative study }\end{array}$ & $\begin{array}{l}\text { Six classes from six schools } \\
\text { with an average number of } \\
\text { students in each class of } 23.8 \\
\text { students and teachers from } \\
\text { six classes. }\end{array}$ & Netherland & $\begin{array}{l}\text { Discovered the process by which schools adopt the } \\
\text { use of tablet computer and determine the factors that } \\
\text { affect the children's attitudes toward using tablet } \\
\text { computer }\end{array}$ \\
\hline $\begin{array}{l}\text { Fekonja-Peklaj, U. and } \\
\text { Marjanovič-Umek, L. [6] }\end{array}$ & Qualitative study & $\begin{array}{l}\text { three first-grade } \text { classes } \\
\text { (ranging from } 20 \text { to } 21 \\
\text { students in each class) }\end{array}$ & Slovenia & $\begin{array}{l}\text { Evaluated the positive and negative effects of using } \\
\text { interactive white board and tablet computer in the } \\
\text { classroom }\end{array}$ \\
\hline $\begin{array}{l}\text { Zhang, M., Trussell, R. P., } \\
\text { Gallegos, B., and Asam, R. R } \\
{[12]}\end{array}$ & $\begin{array}{l}\text { Exploratory } \\
\text { study }\end{array}$ & $\begin{array}{l}7 \text { girls and } 11 \text { boys in the } \\
\text { fourth grade ( } 4 \text { special needs } \\
\text { students, } 6 \text { at-risk students, } 7 \\
\text { typical students, } 1 \text { gifted } \\
\text { student) }\end{array}$ & USA & $\begin{array}{l}\text { Explored the evidence of improvement in students' } \\
\text { learning using math apps and to minimize the } \\
\text { achievement gap between struggling and typical } \\
\text { students }\end{array}$ \\
\hline $\begin{array}{l}\text { Ingram, N., Leadley, S. W., } \\
\text { and Pratt, K. } \\
{[13]}\end{array}$ & $\begin{array}{l}\text { Qualitative } \\
\text { intervention } \\
\text { study }\end{array}$ & $\begin{array}{l}11 \text { female primary and } \\
\text { secondary school teachers } \\
\text { from eight schools }\end{array}$ & New Zealand & $\begin{array}{l}\text { Explored the use of Show and Tell tablet apps in } \\
\text { engaging students based on teacher's perception and } \\
\text { the use of Show and Tell in Mathematics }\end{array}$ \\
\hline $\begin{array}{l}\text { Al-Mashaqbeh, I. and } \mathrm{Al} \\
\text { Shurman, M. } \\
\text { [14] }\end{array}$ & $\begin{array}{l}\text { Quasi- } \\
\text { experiment } \\
\text { control group } \\
\text { design }\end{array}$ & $\begin{array}{l}80 \text { male and female first- } \\
\text { grade students, } \begin{array}{r}\text { school } \\
\text { principal, and principal } \\
\text { assistants }\end{array}\end{array}$ & Jordan & $\begin{array}{l}\text { Investigated the use of tablet that contains e- } \\
\text { textbooks, games, worksheets for the first-grade } \\
\text { students compared with the use of traditional } \\
\text { teaching method }\end{array}$ \\
\hline $\begin{array}{l}\text { Agostinho, S., Tindall-Ford, } \\
\text { S., } \\
\text { Ginns, P., Howard, S. J., } \\
\text { Leahy, W., and Paas, F. } \\
{[15]}\end{array}$ & Experiment & $\begin{array}{l}26 \text { students from the } 3^{\text {rd }} \text { year } \\
\text { and } 35 \text { students from the } 4^{\text {th }} \\
\text { year }\end{array}$ & Australia & $\begin{array}{l}\text { Investigated whether or not the act of tracing on } \\
\text { iPad would be more effective than looking at the } \\
\text { screen in learning temperature line graphs }\end{array}$ \\
\hline $\begin{array}{l}\text { Young, K. } \\
{[16]}\end{array}$ & Survey & $\begin{array}{l}259 \text { teachers from across } 22 \\
\text { schools }\end{array}$ & Ireland & $\begin{array}{l}\text { Examined teachers' attitudes and personal } \\
\text { experiences using iPad in their teaching }\end{array}$ \\
\hline $\begin{array}{l}\text { Shamir-Inbal, T. and Blau, I. } \\
\text { [17] }\end{array}$ & Qualitative & $\begin{array}{l}25 \text { fifth graders, the principal, } \\
\text { and } 4 \text { experienced teachers }\end{array}$ & Israel & $\begin{array}{l}\text { Analyzed the learning activities designed by school } \\
\text { staff using tablet computers }\end{array}$ \\
\hline $\begin{array}{l}\text { Maher D. and Twinning, P. } \\
\text { [7] }\end{array}$ & Case Study & $\begin{array}{l}\text { Two classes from two } \\
\text { primary schools ranged from } \\
100 \text { and } 200 \text { students }\end{array}$ & Australia & $\begin{array}{l}\text { Explored the insights where tablet had been } \\
\text { introduced to the students and implemented in } \\
\text { learning. }\end{array}$ \\
\hline $\begin{array}{l}\text { Schilhab, T. } \\
\text { [18] }\end{array}$ & $\begin{array}{l}\text { Exploratory } \\
\text { research }\end{array}$ & $\begin{array}{l}10 \text { pupils of the } 1^{\text {st }}, 5^{\text {th }}, 6^{\text {th }} \text {, } \\
\text { and } 9^{\text {th }} \text { grade from three } \\
\text { schools }\end{array}$ & Denmark & $\begin{array}{l}\text { Explored the activities that happened during break- } \\
\text { time when school introduced tablet devices and } \\
\text { investigated the changing characteristics. }\end{array}$ \\
\hline $\begin{array}{l}\text { Cantú-Ballesteros, L., Urías- } \\
\text { Murrieta, M., Figueroa- } \\
\text { Rodríguez, S. and Salazar- } \\
\text { Lugo, G. M. } \\
\text { [19] }\end{array}$ & $\begin{array}{l}\text { Quantitative and } \\
\text { a cross-sectional } \\
\text { survey design }\end{array}$ & $\begin{array}{l}88 \text { fifth and sixth-grade } \\
\text { teachers from } 32 \text { schools } \\
\text { from }\end{array}$ & Mexico & $\begin{array}{l}\text { Determined the self-perception of digital abilities of } \\
\text { primary school teachers and their relation to specific } \\
\text { socio-demographic factors. }\end{array}$ \\
\hline
\end{tabular}




\section{RESULT AND DISCUSSION}

According to the aim of this study that intended to map the trends of the studies related to the integration of tablet with learning and its use in primary education. From the selected papers that were investigated, four of them used quantitative research method, and seven of them utilized qualitative research method. In general, qualitative descriptive is the primary method used to explore the phenomena in the schools and to capture the implementation of tablet computer integration with learning in a school context. In addition, to emphasize the research method, the research aims is the next trend in the selected papers, which include (1) to explore the integration and implementation process of tablet computer in learning process, especially the way it is implemented in schools; (2) to discover and to describe the perceptions of students, teachers, or school staff in connection with the tablet use in the classroom; and (3) to analyze the positive and negative effects of using tablet in classroom activities. The adverse effects of using tablet computer were found from the physical point of view since it is constrained so it could affect posture or eyes development. Most of the previous studies only pointed out technical issues and its usage [9].

The next trend captured from the selected papers is the participants involved in the research. According to Table 1, there are four papers that entirely regard teachers as respondents [10], [13], [16], [19], while most papers investigated students' experiences as a major focus of the research with the data gathered from principals, teachers, assistant teachers, and parents.

The previous descriptions presented that most research was conducted using a qualitative approach that only solved the issue based on the perspective of students. It resulted in some limitations of the selected papers. First, there was a lack of data interpretation during the observation of the elementary school students mainly due to the questionnaire that only allowed the researchers to give "yes or no" questions. Next, the data gained through interviews with elementary school students who are still children might be biased [6].

The next discussion is about the systems of tablet integration with learning that was categorized into two different kinds. The first system is 1:1 (one-per-one) device use which indicated that each student used one tablet during the learning session. The second system is when a device was used by many students, which means several students ( 2 or 3 students) use a tablet together in their learning session. Mostly, the papers used the 1:1 system. Based on Maher and Twinning's study [7], students can have more free access through their devices in school that was implementing BYOD (Bring Your Device) instead of using the media supported by the Australian government based on their program. Young also found the effectiveness of using a tablet (iPad) as a learning tool because of its usability and versatility [16].

Such findings may raise the number of students having access to their tablets. Even though the result of a recent survey from We Are Social (2017) showed that tablet-device use decreased by $5 \%$ from its use in the past years, while laptop-device use dropped at $20 \%$, unlike those devices, the number of mobile phones used in daily activity increased by more than $30 \%$ over the past years [20]. According to Walling, tablet computers still offer a higher portability than standard laptops because of their compact size and affordable price compared to PCs for 1:1 learning system implementation at schools [2].

\section{LIMITATIONS}

This study is a review of several studies in the primary education context. Hence, several limitations can be addressed from this study. First, although there are many articles related to the tablet use, there are still limited studies in the primary education context. Mostly, research papers with such theme focus on higher education level. Second, the studies are mostly done in developed countries where it is very rational to draw the line between the budget and the ICT literacy in those countries. Furthermore, it is difficult to draw conclusions based on the results of the studies because there is no standard measurement to highlight their results. In connection with the methodology of this study, this paper has not utilized a qualitative analysis program to minimize any failure in noticing the results. Future studies should minimize the limitations such as by performing metaanalytical studies that have been verified to obtain data with high validity and reliability from the findings.

\section{CONCLUSION}

In this study, a review based on several criteria was conducted to map the trends of some research regarding the integration of tablet devices with learning in primary education. As many as eleven studies that were undertaken from 2013 to 2017 had been identified to match the keywords, namely tablet, mobile device, mobile computer, primary education and elementary education to gather the necessary data. The research findings to answer the research question were identified into several points. First, the most common methodology used in the selected paper is qualitative descriptive approach with the characteristics of exploratory and case study designs. Second, the aims of those studies are (1) to explore the implementation process and design; (2) to describe the perceptions of students, teachers, parents, and school staff while implementing the use of tablet in learning process; and (3) to analyze the positive and negative effects of tablet computer use in learning although the number of studies that relate the findings to physical components, such as the development of posture and eye affected by the use of tablet in classroom activities is still limited. Third, the mode used to conduct the research is 1:1 system, which means one student uses one tablet. There is also some limitation of this study that relates to the specific context and standard measurement. Finally, this paper highlights various potential future research related to the specific review of tablet use in primary education especially the specific methods that can be used to conduct meta-analysis or other research. 


\section{REFERENCES}

[1] M. Prensky, "Digital natives, digital immigrants part 1," Horiz, vol. 9, no. 5, pp. 1-6, 2001.

[2] D. R. Walling, Designing learning for tablet classrooms: Innovations in instruction. Springer Science \& Business Media, 2014.

[3] B. Trilling and C. Fadel, 21st century skills: Learning for life in our times. San Francisco: John Wiley \& Sons, 2009.

[4] J. MacDonald and L. Creanor, Learning with online and mobile technologies: a student survival guide. Surrey: Gower Publishing Ltd., 2012.

[5] C. P. Lim and D. Churcill, "Mobile learning," Interact. Learn. Environ., vol. 24, no. 2, pp. 273-276, 2016.

[6] U. Fekonja-Peklaj and L. Marjanovič-Umek, "Positive and negative aspects of the IWB and tablet computers in the first grade of primary school: a multiple-perspective approach," Early Child Dev. Care, vol. 185, no. 6, pp. 966-1015, 2015.

[7] D. Maher and P. Twining, "Bring your own device - a snapshot of two Australian primary schools," Educ. Res., vol. 59, no. 1, pp. 7378, 2017.

[8] M. Ally, V. Balaji, A. Abdelbaki, and R. Cheng, "Use of Tablet Computers to Improve Access to Education in a Remote Location," $J$. Learn. Dev., vol. 4, no. 2, pp. 221-228, 2017.

[9] E. Binboğa and O. Korhan, "Posture, Musculoskeletal Activities, and Possible Musculoskeletal Discomfort Among Children Using Laptops or Tablet Computers for Educational Purposes: A Literature Review," J. Sci. Educ. Technol., vol. 23, no. 5, pp. 605-616, 2014.

[10] G. M. Johnson, "Using Tablet Computers with Elementary School Students with Special Needs: The Practices and Perceptions of Special Education Teachers and Teacher Assistants," Can. J. Learn. Technol., vol. 39, no. 4, 2013.

[11] A. J. A. M. van Deursen, S. Ben Allouch, and L. P. Ruijter, "Tablet use in primary education: Adoption hurdles and attitude determinants," Educ. Inf. Technol., vol. 21, no. 5, pp. 971-990, 2016.
[12] M. Zhang, R. P. Trussell, B. Gallegos, and R. R. Asam, "Using math apps for improving student learning: An exploratory study in an inclusive fourth grade classroom," TechTrends, vol. 59, no. 2, pp. 32$39,2015$.

[13] N. Ingram, S. Williamson-Leadley, and K. Pratt, "Showing and telling: using tablet technology to engage students in mathematics," Math. Educ. Res. J., vol. 28, no. 1, pp. 123-147, 2015.

[14] I. Al-Mashaqbeh and M. Al Shurman, "The Adoption of Tablet and E-Textbooks: First Grade Core Curriculum and School Administration Attitude," J. Educ. Pract., vol. 6, no. 21, pp. 188-194, 2015.

[15] S. Agostinho, S. Tindall-Ford, P. Ginns, S. J. Howard, W. Leahy, and F. Paas, "Giving Learning a Helping Hand: Finger Tracing of Temperature Graphs on an iPad," Educ. Psychol. Rev., vol. 27, no. 3, pp. 427-443, 2015.

[16] K. Young, "Teachers' Attitudes to using iPads or Tablet Computers; Implications for Developing New Skills, Pedagogies and SchoolProvided Support," TechTrends, vol. 60, no. 2, pp. 183-189, 2016.

[17] T. Shamir-Inbal and I. Blau, "Developing digital wisdom by students and teachers: the impact of integrating tablet computers on learning and pedagogy in an elementary school," J. Educ. Comput. Res., vol. 54, no. 7, pp. 967-996, 2016.

[18] T. Schilhab, "Impact of iPads on break-time in primary schools - a Danish context," Oxford Rev. Educ., vol. 43, no. 3, pp. 261-275, 2017.

[19] L. Cantú-Ballesteros, M. Urías-Murrieta, S. Figueroa-Rodríguez, and G. M. Salazar-Lugo, "Teacher's Digital Skills in Relation to Their Age, Gender, Time of Usage and Training with a Tablet," J. Educ. Train. Stud., vol. 5, no. 5, pp. 46-57, 2017.

[20] S. Kemp, "DIGITAL IN 2017: GLOBAL OVERVIEW," We Are Social, 2017. [Online]. Available: https://wearesocial.com/specialreports/digital-in-2017-global-overview. [Accessed: 07-Jul-2017]. 